\title{
Cholinergic Modulation of Excitatory Synaptic Transmission in the CA3 Area of the Hippocampus
}

\author{
Kaspar E. Vogt and Wade G. Regehr \\ Department of Neurobiology, Harvard Medical School, Boston, Massachusetts 02115
}

Cholinergic innervation of the hippocampus has been implicated in memory formation and retrieval. Here we study cholinergic modulation of excitatory transmission in the CA3 area of the rat hippocampus. We used a combination of optical measurements of presynaptic calcium and electrophysiological measurements of synaptic currents to study associationalcommissural $(\mathrm{A} / \mathrm{C})$ and mossy fiber (MF) synapses in brain slices. Direct synaptic modulation mediated by ACh receptors is only evident at the $\mathrm{A} / \mathrm{C}$ synapse, where synaptic inhibition primarily reflects presynaptic calcium channel inhibition mediated by muscarinic receptors. MF synapses can, however, be indirectly modulated by muscarinic receptor activation. Muscarine elevates the firing rate of inhibitory cells, which increases GABA release and inhibits MF synapses by activating presynaptic $\mathrm{GABA}_{\mathrm{B}}$ receptors. Muscarine also depolarizes dentate granule cells and elevates their rate of firing. This leads to synaptic enhancement when combined with the use-

The hippocampal formation has been implicated in memory formation in many mammals including man (Squire, 1998). Substances that interact with receptors for the neurotransmitter acetylcholine have been shown to interfere with memory (Deutsch and Rocklin, 1967; Safer and Allen, 1971). Moreover, synaptic plasticity in the hippocampus, widely believed to underlie some forms of learning and memory, can be influenced by drugs that act at acetylcholine receptors (Huerta and Lisman, 1993; Hasselmo et al., 1995). Loss of cholinergic innervation may underlie some of the pathology in Alzheimer's disease (Bartus et al., 1982; Coyle et al., 1983).

Cholinergic effects are mediated by two broad classes of receptors for acetylcholine: muscarinic receptors, which are large transmembrane G-protein-coupled receptors (Hulme et al., 1990), and nicotinic receptors, which form nonselective cation channels (Albuquerque et al., 1995; Dani and Mayer, 1995; Boyd, 1997). Presynaptic inhibitory actions and postsynaptic excitatory actions have been documented for muscarinic receptors (Rouse et al., 1999). Activation of nicotinic receptors can excite cells by evoking inward currents (Albuquerque et al., 1995; Alkondon et al., 2000)

Received Aug. 24, 2000; revised Oct. 16, 2000; accepted Oct. 23, 2000.

This work was supported by National Institutes of Health PPG Grant P01N538312. K.E.V. was supported by a grant from the Swiss National Science Foundation. We thank Bruce Peters for invaluable contributions in the initial stage of this project. We also thank Matthew Xu-Friedman, Chinfei Chen, Adam Carter, Anatol Kreitzer, and Kelly Foster for helpful comments on this manuscript.

Correspondence should be addressed to Dr. Wade Regehr, Department of Neurobiology, 220 Longwood Avenue, Boston, MA 02115. E-mail: wade_regehr@ hms.harvard.edu.

Copyright (C) 2001 Society for Neuroscience $\quad 0270-6474 / 01 / 210075-09 \$ 15.00 / 0$ dependent facilitation of MF synapses. In addition we were unable to evoke an increase in presynaptic calcium levels in MF boutons with local application of nicotinic receptor agonists. This finding does not support a leading hypothesis for MF modulation in which activation of presynaptic nicotinic receptors enhances transmission directly by elevating presynaptic calcium levels. However, indirect synaptic modulation could arise from nicotinic excitation of inhibitory neurons. Thus, to understand cholinergic modulation within the CA3 region, it is necessary to take into account secondary actions on synapses arising from other chemical messengers released by other cell types and to consider effects on firing patterns of presynaptic cells, which in turn influence release via use-dependent synaptic plasticity.

Key words: acetylcholine; hippocampus; associational-commissural; mossy fiber; muscarine; nicotine; presynaptic; calcium; fura-2; magnesium green

and may also have modulatory presynaptic effects (McGehee et al., 1995; Gray et al., 1996).

Here we investigate the influence of cholinergic receptor activation on excitatory glutamatergic transmission in the CA3 area of the hippocampus. Cholinergic innervation of the hippocampus arrives mainly through the fornix/fimbria and originates in the medial septal nuclei and the vertical limb of the nucleus of the diagonal band of Broca (Gray and McNaughton, 1983). Muscarinic and nicotinic receptors are found on both principal cells and interneurons in the CA3 region (Levey et al., 1995; Albuquerque et al., 1997; McQuiston and Madison, 1999a).

We have focused our experiments on synaptic transmission via the mossy fiber (MF) system and the associational-commissural (A/C) fiber system. MF synapses provide glutamatergic input from dentate gyrus (DG) granule cells. MFs run in a well delineated tract within a distinct morphological layer in CA3, the stratum lucidum, and contact the proximal apical dendrites of CA3 pyramidal cells (Amaral and Dent, 1981). A/C synapses are a dense associative network of ipsilateral and contralateral excitatory connections between CA3 pyramidal cells that are found throughout the stratum radiatum of the CA3 (Amaral and Witter, 1989). Previous reports indicate that to some degree cholinergic modulation of excitatory synapses occurs throughout this region (Williams and Johnston, 1990; Hasselmo and Schnell, 1994), although the underlying mechanisms have not been investigated in detail. For example, it has been shown that the MF synapse is inhibited by muscarine (Williams and Johnston, 1990), and it has been reported that activation of calcium-permeable nicotinic receptors can modulate MF synapses by elevating presynaptic calcium levels (Gray et al., 1996). Thus an important part of under- 
standing ACh control of hippocampal function is to elucidate more fully the effects of ACh on excitatory transmission in the CA3 region.

We used a combination of optical measurements of presynaptic calcium and electrophysiological measurements of synaptic currents to study $\mathrm{A} / \mathrm{C}$ and $\mathrm{MF}$ synapses in brain slices from rats. Direct synaptic modulation mediated by ACh receptors is only evident at the $\mathrm{A} / \mathrm{C}$ synapse, where synaptic inhibition reflects inhibition of presynaptic calcium channels mediated by muscarinic receptors. In addition, we found that MF synapses can be modulated by muscarine application by multiple indirect mechanisms. This study illustrates that in a highly interconnected region synaptic modulation cannot be understood solely by consideration of direct effects. No evidence of presynaptic nicotinic modulation of the MF synapse was apparent.

\section{MATERIALS AND METHODS}

Slices were cut from Sprague Dawley rats using standard procedures. Animals 15-21 d old were used, except in experiments on nicotinic receptor activation in which 18- to 28 -d-old rats were used. Animals were decapitated under deep Halothane anesthesia, and their brains were rapidly removed and placed in ice-cold dissection solution equilibrated with 95\% $\mathrm{O}_{2}$ and $5 \% \mathrm{CO}_{2}$. The dissection solution contained (in $\mathrm{mm}$ ): $\mathrm{NaCl} 87$, sucrose 75, $\mathrm{NaHCO}_{3} 26$, glucose 25, $\mathrm{KCl} 2.5, \mathrm{NaH}_{2} \mathrm{PO}_{4} 1.25, \mathrm{MgCl}_{2} 7$, and $\mathrm{CaCl}_{2}$ 0.5. The hippocampi were dissected and placed onto agar blocks, and their longitudinal axis was straightened. Transverse slices $300 \mu \mathrm{m}$ thick were cut on a vibrating microtome (Leica VT1000) in ice-cold dissection solution. They were transferred to a holding chamber at $32^{\circ} \mathrm{C}$ in the dissection solution. After $20 \mathrm{~min}$ the solution was changed to artificial CSF (ACSF) equilibrated with $95 \% \mathrm{O}_{2}$ and $5 \% \mathrm{CO}_{2}$. ACSF contained (in $\mathrm{mM}$ ): $\mathrm{NaCl} 125, \mathrm{NaHCO}_{3} 26$, glucose 25, $\mathrm{KCl} 2.5, \mathrm{NaH}_{2} \mathrm{PO}_{4} 1.25, \mathrm{MgCl}_{2}$ 2, and $\mathrm{CaCl}_{2} 3$. After a total of $1 \mathrm{hr}$ at $32^{\circ} \mathrm{C}$ the slices were then held at room temperature. In cases in which the cell bodies of the dentate gyrus granule cells were separated from the MF synapses, slices were placed under a dissecting scope, and the MF tract was cut distal to the hilus of the dentate gyrus. Experiments were done at room temperature. 3-[(R)-2-Carboxypiperazin-4-yl]-propyl-1-phosphonic acid [( $R)$-CPP], $\left(2 S, 1^{\prime} S, 2^{\prime} S\right)-2-$ (carboxy-cyclopropyl) (L-CCG-I), (+)-(2S)-5,5-dimethyl-2-morpholineatic acid (SCH50911), and 2,3-dioxo-6-nitro-1,2,3,4-tetrahydrobenzo(f)quinoxinaline-7-sulfonamide disodium (NBQX) were obtained from Tocris; bicuculline, baclofen, and muscarine were from Sigma (St. Louis, MO). Results are reported as the mean \pm SEM.

Presynaptic labeling and $\mathrm{Ca}$ measurements. Presynaptic fibers were labeled with AM esters of either magnesium green or fura-2 (Molecular Probes, Eugene, OR) as described previously (Regehr and Tank, 1991; Regehr and Atluri, 1995). For MF labeling the injection pipette was placed onto the stratum lucidum, perpendicular to the orientation of the fibers. For A/C fiber labeling the injection pipette was placed midway between the stratum lucidum and stratum moleculare in CA3. In most cases the orientation in which the slices were cut preserved a several millimeter long MF tract that ran almost parallel to the surface of the slice. Individual MF boutons and axons were visible at high magnifications. After labeling in the stratum radiatum, a pattern of fine fibers interspersed with boutons $\sim 1 \mu \mathrm{m}$ in diameter was observed $400-600 \mu \mathrm{m}$ from the site of labeling. Slices were placed under an upright microscope (Olympus BX50WI) and continuously superfused with ACSF equilibrated with $95 \% \mathrm{O}_{2}$ and $5 \% \mathrm{CO}_{2}$. They were visualized using a $40 \times$ water-immersion lens. A small region of the labeled fibers was illuminated, and the fluorescence signal was measured with a photodiode (Regehr and Atluri, 1995). The signals from the photodiode were digitized (Instrutech) at $5 \mathrm{kHz}$ and captured with a Macintosh personal computer using IGOR Pro (Wavemetrics) software (Herrington and Bookman, 1995). Action potential-induced signals were low-pass filtered at $500 \mathrm{~Hz}$, and drug application-induced transients were low-pass filtered at $100 \mathrm{~Hz}$ with digital-filtering algorithms. Signals were transformed into $\Delta F / F$ measurements. With increasing calcium concentrations, magnesium green fluorescence increases, whereas fura-2 fluorescence decreases for $380 \mathrm{~nm}$ excitation and increases for $350 \mathrm{~nm}$ excitation.

Electrophysiological recordings. Whole-cell recordings of CA3 pyramidal cells were obtained under visual control. Glass pipettes (2-3 M $\Omega$ ) were filled with an internal solution containing (in mM): $\mathrm{CsCl} \mathrm{100,} \mathrm{CsF}$ 35, EGTA 10, and HEPES 10, pH 7.4. Access resistances ranged be- tween 7 and $15 \mathrm{M} \Omega$ and were continuously monitored. To measure NMDA currents, the cells were held at $+30 \mathrm{mV}$.

Extracellular glass stimulus electrodes were filled with ACSF and placed into the stratum radiatum and stratum lucidum. Square pulses $(1-5 \mu \mathrm{A})$ of $0.3 \mathrm{msec}$ duration were used to evoke EPSCs of $100-500 \mathrm{pA}$. MF responses were identified because of their large amount of shortterm facilitation. If identification was crucial, the presynaptic metabotropic glutamate receptor agonist L-CCG-I $(10 \mu \mathrm{M})$ was used to identify positively the origin of MF EPSCs (Kamiya et al., 1996). For cellattached recordings, patch pipettes with 3-5 $\mathrm{M} \Omega$ resistance were filled with a solution containing (in $\mathrm{mM}$ ): $\mathrm{NaCl} 165$, HEPES 10, glucose 25, $\mathrm{KCl} 2.5, \mathrm{NaH}_{2} \mathrm{PO}_{4} 1.25, \mathrm{MgCl}_{2}$, and $\mathrm{CaCl}_{2}$,, $\mathrm{pH}$ 7.3. After establishing a cell-attached configuration, the viability of the cell was assessed using a brief focal $\mathrm{KCl}$ application. Only cells that exhibited clearly distinguishable action potentials were used for further studies. The whole-cell recordings in current-clamp mode were performed with an internal solution that contained (in $\mathrm{mm}$ ): $\mathrm{KMeSO}_{4}$ 130, EGTA 0.5, HEPES 10, $\mathrm{Na}_{2} \mathrm{ATP} 4, \mathrm{MgCl}_{2}$ 6, and NaGTP 0.3, pH 7.4.

Focal application to labeled MF tracts. Drugs were loaded into glass pipettes with a opening diameter of $2-4 \mu \mathrm{m}$ attached to a pneumatic injection system (PV820; WPI). Pressure pulses of $1 \mathrm{sec}$ duration and 1-5 psi pressure were used to eject drugs. The system was calibrated with a solution containing fast green before every experimental run, to prevent leaking of pipette solution or backfilling of pipettes with bath solution. Excitation filters with center frequencies of 350 and $380 \mathrm{~nm}$ were mounted on a filter wheel (Lambda 10; Sutter Instruments). Ten trials were performed for each excitation wavelength, and $\Delta F / F$ transients were calculated. Filters were switched two or three times for a total of 40-60 traces. Fura-2 fluorescence traces were not inverted for these experiments.

\section{RESULTS}

\section{Fluorometric detection of calcium influx}

Synaptic modulators in the vertebrate CNS often act by altering action potential-driven presynaptic calcium entry (Dittman and Regehr, 1996; Wu and Saggau, 1997). This makes it highly desirable to monitor presynaptic calcium influx in characterizing cholinergic modulation of synapses in the CA3 region. Such measurements are possible, provided presynaptic boutons can be selectively loaded with calcium-sensitive indicators. At many synapses, including the $\mathrm{MF} \rightarrow \mathrm{CA} 3$ pyramidal cell synapse (Regehr et al., 1994), this can be accomplished by locally applying a membrane-permeant form of a calcium indicator to a fiber tract (Fig. 1A). The cell-permeant AM ester is hydrolyzed intracellularly into the membrane-impermeant fluorescent indicator dye. After allowing time for diffusion, a distinct tract of MFs is labeled with the indicator (Fig. 1B). By illuminating a small area of the labeled fibers far from the site of application, action potential-driven calcium influx can be measured as the $\Delta F / F$ of the fluorescence transients evoked by extracellular stimulation of the MF bundle. This provides an aggregate measure of many activated MFs and contains signals from both synaptic boutons and axons (Regehr, 1999). These fluorescence transients are dominated by calcium transients in MF boutons onto CA3 pyramidal cells, which are large (3-6 $\mu \mathrm{m}$ in diameter) and have a volume much greater than that of the much thinner axons.

We tested two calcium-sensitive indicators: fura-2, which is a high-affinity dye with a dissociation constant of 200 nм (Grynkiewicz et al., 1985), and magnesium green (Zhao et al., 1996), which is a low-affinity indicator with a dissociation constant of 6 $\mu \mathrm{M}$ (Fig. $1 C, D$ ). The decay time course of the fluorescence transients after single stimuli was slower for fura- 2 compared with that for magnesium green $\left[t_{1 / 2}, 175 \pm 24 \operatorname{msec}(N=4)\right.$ compared with $30 \pm 3 \mathrm{msec}(N=6)$ ] (Fig. $\left.1 C_{1}, D_{1}\right)$. In addition, the second $\Delta F / F$ response to a pair of stimuli was decreased for fura-2 $(0.61 \pm 0.1 ; N=4)$ but not for magnesium green $(1.02 \pm 0.02$; $N=6$ ) (Fig. $1 C_{2}, D_{2}$ ). This is consistent with previous studies at 

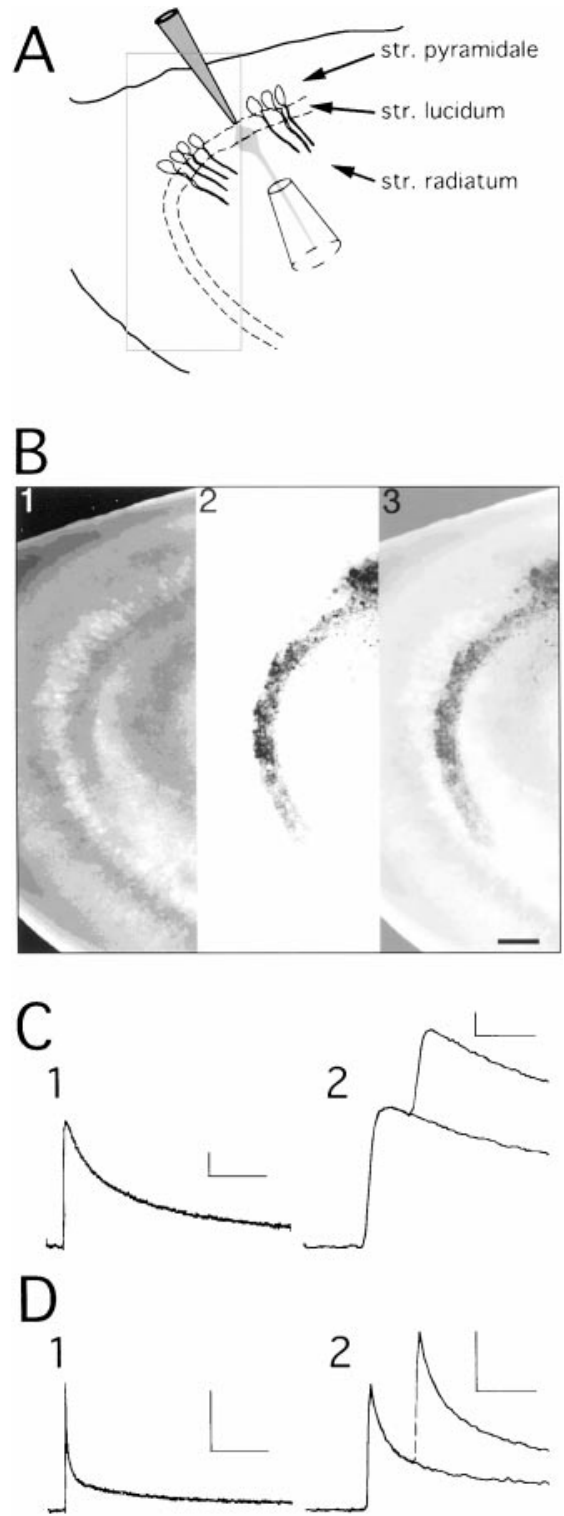

Figure 1. Measurements of presynaptic calcium transients in MFs. $A$, Schematic showing the placement of the local superfusion system for labeling hippocampal mossy fibers. A rectangle marks the area shown in $B$. $B$, Hippocampal CA3 region of a slice in which MFs were labeled with magnesium green. A bright-field image (1), an image of magnesium green fluorescence converted to gray scale with regions of intense fluorescence appearing dark (2), and an overlay of the two (3) are shown. Scale bar, 100 $\mu \mathrm{m}$. $C, D$, Fluorescence transients evoked by extracellular MF stimulation in slices in which MFs were labeled with fura-2 $(C)$ and magnesium green $(D)$. A single stimulus was used (1), and fluorescence transients were evoked by a stimulus pair $40 \mathrm{msec}$ apart (2). The $380 \mathrm{~nm}$-evoked fura-2 fluorescence has been inverted for clarity in this and the next figure. Calibration: vertical, $1 \% \Delta F / F$; horizontal, $500 \mathrm{msec}(1), 50 \mathrm{msec}$ (2). str, Stratum.

other presynaptic boutons (Regehr and Atluri, 1995; Feller et al., 1996; Regehr, 1999) and suggests that the calcium transients in MF boutons were sufficiently large that fura-2 could not faithf ully report them but magnesium green could.

A/C fibers were labeled in a similar manner by local application of dye to the stratum radiatum (Fig. $2 A$ ). The morphology of the A/C system (Amaral and Witter, 1989) is not as well suited to this labeling method as is that of the MF system. In contrast to the
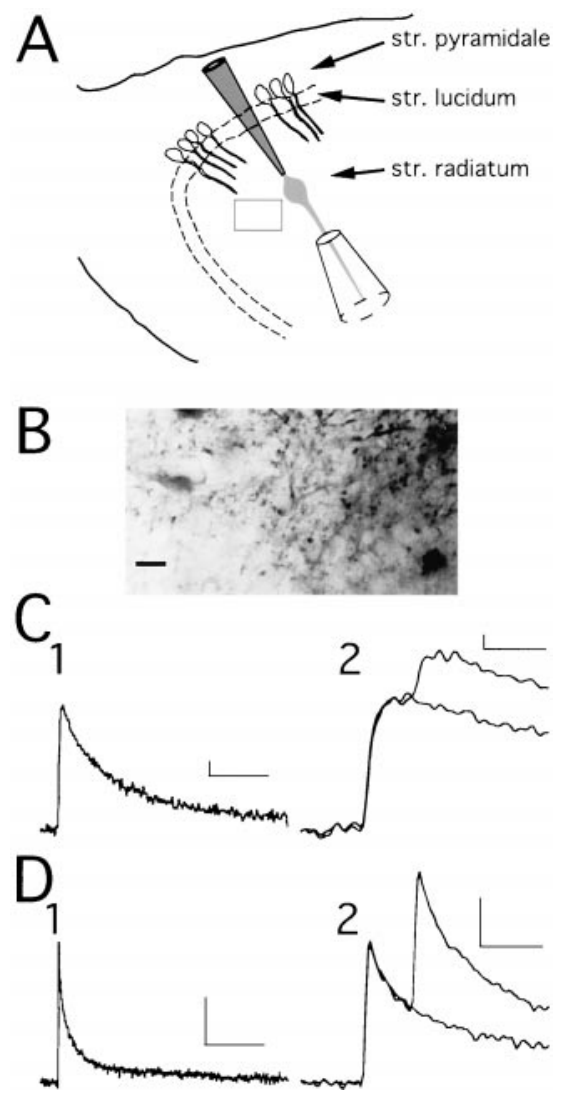

Figure 2. Measurements of presynaptic calcium transients in associational-commissural fibers. $A$, Schematic showing the labeling of $\mathrm{A} / \mathrm{C}$ fibers. The area shown in $B$ is marked with a rectangle. $B$, Highmagnification image of the stratum radiatum in a magnesium greenlabeled slice. Fluorescence signals are converted to a gray scale image with dark structures representing high-fluorescence intensity. Scale bar, 10 $\mu \mathrm{m}$. $C, D$, Fluorescence transients evoked by extracellular stimulation in the stratum radiatum in slices labeled with fura-2 $(C)$ and magnesium green $(D)$. Fluorescence transients were evoked by a single stimulus $(1)$ and a stimulus pair $40 \mathrm{msec}$ apart (2). Calibration: vertical, $0.25 \% \Delta F / F$; horizontal, $500 \mathrm{msec}(1), 50 \mathrm{msec}(2)$.

MF bundle, axons within the A/C system fibers are highly divergent. Consequently the density of labeled fibers decreases rapidly as a function of the distance from the site of dye application. Because unwanted nonspecific labeling is significant near the loading site, calcium must be monitored at some distance, resulting in dim fluorescence signals (Fig. 2B). To prevent a contribution from recurrent excitation, we blocked ionotropic glutamate receptors during recordings of presynaptic calcium transients from $\mathrm{A} / \mathrm{C}$ fibers. As for $\mathrm{MFs}$, calcium transients in the $\mathrm{A} / \mathrm{C}$ system were sufficiently large that a low-affinity indicator such as magnesium green was needed to quantify changes in calcium influx. This is reflected in the decay time of fluorescence transients after single stimuli for fura-2 compared with that for magnesium green $\left[t_{1 / 2}, 204 \pm 13 \mathrm{msec}(N=3)\right.$ compared with $43 \pm 2 \mathrm{msec}(N=4)$ ] (Fig. $\left.2 C_{1}, D_{1}\right)$. Moreover, the second $\Delta F / F$ response to a pair of stimuli was smaller than the first for fura-2 $(0.51 \pm 0.05 ; N=3)$ but not for magnesium green $(0.97 \pm 0.02$; $N=4$ ) (Fig. $2 C_{2}, D_{2}$ ).

To quantify changes in presynaptic calcium entry with optical methods, it is desirable that the indicator does not distort the calcium signal and that the signal arises from calcium entry through presynaptic voltage-gated calcium channels (Regehr and 
Atluri, 1995). For both MF and A/C fibers, magnesium green $\Delta F / F$ transients decayed fast and added linearly during repetitive stimuli in both fiber tracts, indicating that the calcium signals do not saturate the dye. The relative volume of these boutons compared with that of the axon and the greater density of calcium channels in boutons compared with that of the axons argue that most of this signal arises from presynaptic boutons. On the basis of the very rapid rise time of these calcium signals, most of this fluorescent signal arises from calcium influx in response to an action potential. It is therefore possible to quantify changes in action potential-driven calcium influx into both of these types of presynaptic terminals by measuring magnesium green fluorescence transients.

\section{The relationship between calcium influx and release for MF and A/C synapses}

As a first step in determining the mechanism of action of $\mathrm{ACh}$ in synaptic modulation, we determined the effect of modulating calcium entry on neurotransmitter release. The quantification of neurotransmitter release in the CA3 region is complicated by prominent recurrent excitation (Christian and Dudek, 1988) and inhibition (Miles and Wong, 1987). As a result, whole-cell measurements of AMPA receptor-mediated currents are contaminated by large recurrent inhibitory currents mediated by $\mathrm{GABA}_{\mathrm{A}}$ receptors. Removal of these inhibitory responses with $\mathrm{GABA}_{\mathrm{A}}$ receptor antagonists is impractical because the slices become epileptic. We avoided such problems by including both AMPA (NBQX, $10 \mu \mathrm{M}$ ) and $\mathrm{GABA}_{\mathrm{A}}$ (bicuculline, $20 \mu \mathrm{M}$ ) receptor antagonists. Thus we were able to quantify synaptic strength, free from the complication of recurrent synaptic activity, by monitoring monosynaptic excitatory NMDA receptor (NMDAR)mediated EPSCs from MF and A/C synapses.

Altering the external calcium concentration $\left(\mathrm{Ca}_{\mathrm{e}}\right)$ is a convenient way of controlling calcium entry into presynaptic terminals to determine the relationship between calcium influx and release. To avoid changes in fiber excitability, the total amount of divalent cations was held constant by substituting $\mathrm{Mg}$ for $\mathrm{Ca}$. We did not observe changes in the presynaptic fiber volley in the different calcium concentrations under these conditions (data not shown). Reducing $\mathrm{Ca}_{\mathrm{e}}$ from 3 to $1 \mathrm{~mm}$ decreases presynaptic calcium entry to $\sim 50 \%$ into both $\mathrm{MF}$ and $\mathrm{A} / \mathrm{C}$ synapses (Fig. $3 A$ ). Both $\mathrm{A} / \mathrm{C}$ and $\mathrm{MF}$ synapses showed a sublinear relationship between extracellular calcium concentration and presynaptic calcium influx (Fig. 3B), consistent with saturation of influx through voltagegated calcium channels (Mintz et al., 1995). The relationships between $\Delta F / F$ and $\mathrm{Ca}_{\mathrm{e}}$ for both synapses are not significantly different.

Synaptic strength was more sensitive to changes in $\mathrm{Ca}_{\mathrm{e}}$ than was calcium entry. Lowering $\mathrm{Ca}_{\mathrm{e}}$ from 3 to $1 \mathrm{~mm}$ reduces NMDAR-mediated EPSCs to $\sim 10 \%$ for MF synapses and $\sim 20 \%$ for A/C synapses (Fig. 3C). For both $\mathrm{A} / \mathrm{C}$ and MF synapses the relationship between calcium influx per action potential $\left(\mathrm{Ca}_{\mathrm{i}}\right)$ and EPSC amplitude was well fit by the following equation:

$$
\operatorname{EPSC}\left(C a_{i}\right)=\operatorname{EPSC}_{\text {max }}\left(\frac{C a_{i}}{C a_{i}+K_{D}}\right)^{n},
$$

where EPSC and $\mathrm{Ca}_{\mathrm{i}}$ are normalized to values in $3 \mathrm{~mm} \mathrm{Ca}$, $\mathrm{EPSC}_{\text {max }}$ is the maximal EPSC amplitude, $K_{D}$ is the apparent affinity constant of the process, and $n$ is the power law exponent (Fig. 3D,E, solid lines). These fits approximate the relationship between calcium influx and release for these synapses when external calcium is systematically varied. The power law exponent
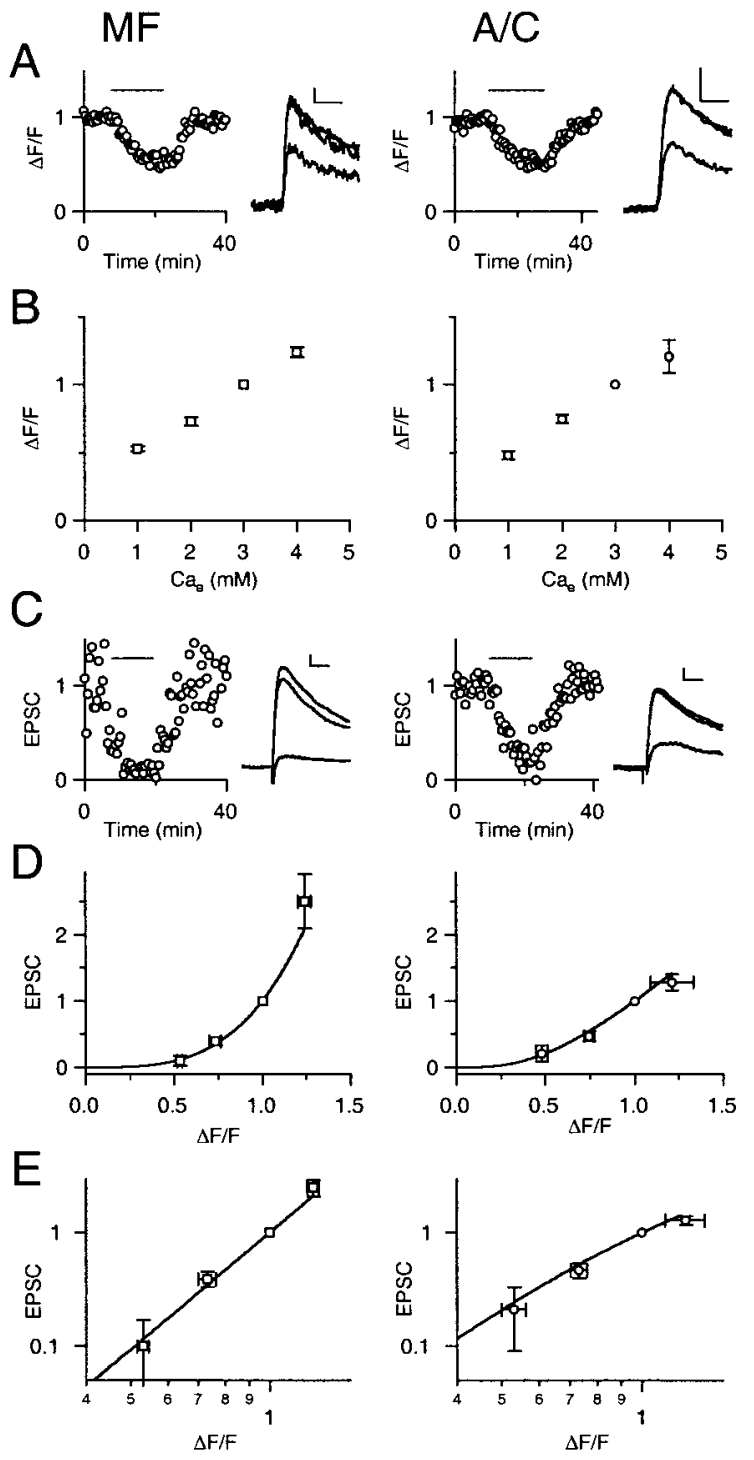

Figure 3. The effect of external calcium on presynaptic calcium influx and synaptic strengths. $A$, Reduction in peak magnesium green $\Delta F / F$ during application of $1 \mathrm{mM} \mathrm{Ca}_{\mathrm{e}}$ (horizontal line) for $\mathrm{MF}$ (left) and $\mathrm{A} / \mathrm{C}$ (right) fibers. The control solution contained $3 \mathrm{mM} \mathrm{Ca}_{\mathrm{e}}$. Insets, Averages of $10-20$ $\Delta F / F$ transients before, during (smallest trace), and after the application of $1 \mathrm{~mm} \mathrm{Ca}_{\mathrm{e}}$. Calibration: vertical, $0.2 \% \Delta F / F$; horizontal, $10 \mathrm{msec}$. $B$, Relationship between peak $\Delta F / F$ and $\mathrm{Ca}_{\mathrm{e}}$ in $\mathrm{MF}$ and $\mathrm{A} / \mathrm{C}$ fibers. The relative change in $\Delta F / F$ for different $\mathrm{Ca}_{\mathrm{e}}$ values was measured and normalized to that of control conditions. $C$, Reduction in NMDAR-mediated EPSC amplitude for $\mathrm{MF}$ and $\mathrm{A} / \mathrm{C}$ fibers for the same reduction in $\mathrm{Ca}_{\mathrm{e}}$. Insets, Averages of 10-20 NMDAR-mediated EPSCs before, during, and after the application of $1 \mathrm{~mm} \mathrm{Ca}_{\mathrm{e}}$. Calibration: vertical, $20 \mathrm{pA}$; horizontal, $20 \mathrm{msec}$. $D, E$, The relationships between EPSC amplitude and peak $\Delta F / F$ normalized to control conditions and plotted on linear scales $(D)$ and on log scales $(E)$. Fits in $D$ and $E$ are to Equation 1 with $\mathrm{EPSC}_{\max }, K_{\mathrm{D}}$, and $n$ being $\gg 50,19.6$, and 3.63, respectively, for the MF synapse and 14.2, 0.99 , and 3.86 , respectively, for the $\mathrm{A} / \mathrm{C}$ synapse.

is similar at both synapse types, 3.6 for the MF synapse and 3.9 for the $\mathrm{A} / \mathrm{C}$ synapse. The $\mathrm{A} / \mathrm{C}$ synapse shows clear signs of saturation of the release process, but the MF synapse does not.

\section{The effects of presynaptic modulators on calcium entry and release}

To examine direct presynaptic actions of muscarine, we cut the MF bundle to disrupt the connection between the dentate gyrus 
granule cells and the MF synapses and blocked $\mathrm{GABA}_{\mathrm{B}}$ receptors (except when we were testing the effects of activating $\mathrm{GABA}_{\mathrm{B}}$ receptors). We compared muscarinic effects with those of other neuromodulators: the metabotropic glutamate receptor II (mGluRII) agonist L-CCG-I $(10 \mu \mathrm{M})$ and the $\mathrm{GABA}_{\mathrm{B}}$ receptor agonist baclofen $(10 \mu \mathrm{M})$. The mGluRII agonists have become useful tools in distinguishing MF synapses, because they inhibit MF synapses and do not affect $\mathrm{A} / \mathrm{C}$ synapses (Kamiya et al., 1996). Both $\mathrm{MF}$ and $\mathrm{A} / \mathrm{C}$ fibers are thought to be inhibited by activation of $\mathrm{GABA}_{\mathrm{B}}$ receptors.

Examples illustrating the actions of different agonists on calcium influx and synaptic transmission are shown for the MF synapse (Fig. 4A) and the A/C synapse (Fig. 4B). At the MF synapse, baclofen decreased presynaptic calcium entry to $76 \%$ of control and EPSC amplitude to $12 \%$ of control, L-CCG-I decreased calcium influx to $62 \%$ of control and synaptic release to $26 \%$ of control, and muscarine $(10 \mu \mathrm{M})$ had no effect on either the presynaptic calcium signal or synaptic release. In the A/C system, baclofen also reduced calcium entry (64\% of control) and EPSC amplitude (32\% of control), muscarine $(10 \mu \mathrm{M})$ decreased calcium influx to $74 \%$ of control and synaptic release to $52 \%$ of control, and L-CCG-I was without effect on A/C synapses.

The measurements of calcium influx and the relationships between calcium influx and EPSC amplitude of Figure 3 provided important insight into the mechanism of synaptic modulation. If the EPSC versus $\Delta F / F$ in the presence of the modulator falls on the line determined in Figure 3, it suggests that the neuromodulator affects release primarily by altering calcium influx. This appears to be the case for mGluRII inhibition of MF synapses and inhibition of $\mathrm{A} / \mathrm{C}$ synapses by activation of either $\mathrm{GABA}_{\mathrm{B}}$ or muscarine receptors. For $\mathrm{GABA}_{\mathrm{B}}$ inhibition of $\mathrm{MF}$ synapses the point relating EPSC and $\Delta F / F$ is significantly below the line, which suggests that although the decrease in calcium influx contributes to synaptic inhibition, another mechanism, one that is independent of presynaptic calcium signaling, also participates.

Thus, these receptors have very different direct effects on these two types of synapses. Both $\mathrm{MF}$ and $\mathrm{A} / \mathrm{C}$ synapses are inhibited by activation of $\mathrm{GABA}_{\mathrm{B}}$ receptors. In contrast there is a selective effect of mGluRII receptor agonists, which directly inhibit MF synapses but not $\mathrm{A} / \mathrm{C}$ synapses. Muscarine is also selective but inhibits $\mathrm{A} / \mathrm{C}$ synapses without directly affecting MF synapses.

\section{Indirect effects of muscarine on MF synapses}

Although muscarinic inhibition of MF synapses has been reported previously (Williams and Johnston, 1990), we observed no such inhibition for our experimental conditions. However, in our experiments we had severed connections from the dentate region and included $\mathrm{GABA}_{\mathrm{B}}$ receptor antagonists to allow us to study direct synaptic inhibition in isolation. Activation of muscarinic receptors can also affect neuronal excitability, which raises the possibility that activation of muscarinic receptors might have indirect effects on excitatory synapses in the CA3 region. Muscarine increases interneuronal firing (McQuiston and Madison, $1999 \mathrm{~b}$ ), and both A/C and MF synapses are sensitive to $\mathrm{GABA}_{\mathrm{B}}$ receptor activation (Fig. $4 A, B$ ). We therefore tested the possibility that muscarine could indirectly affect synapses in the CA3 region by causing interneurons to fire at high rates, thereby leading to a sufficient buildup of GABA to inhibit synapses.

We performed a number of experiments to examine the effects of muscarine on the firing of CA3 interneurons located in stratum lucidum and stratum radiatum. A whole-cell current-clamp recording of CA3 interneurons revealed that muscarine slowly depolarized the interneuron (McQuiston and Madison, 1999b) and led to sustained spiking (Fig. $5 A_{1}$ ). Cell-attached recordings were used subsequently to avoid disturbance of the ionic composition and excitability of the cell. Action potential frequencies were very low in the conditions used for MF NMDAR EPSC recordings (control) and were increased significantly by muscarine (Fig. $5 \mathrm{~A}_{2}$ ). Muscarine increased the mean firing rate of CA3 interneurons from $0.03 \pm 0.01 \mathrm{~Hz}(N=4)$ for control conditions to $1.5 \pm 0.9 \mathrm{~Hz}(N=4)\left(\right.$ Fig. $\left.5 A_{3}\right)$.

We also measured the effect of muscarine on spontaneous IPSCs (sIPSCs) in CA3 pyramidal neurons. This provided for an average sample of interneuronal activity and thereby provided for a more realistic measure of the increase in GABA release than did measuring the activity of individual neurons. These experiments were performed in the presence of NBQX $(10 \mu \mathrm{M})$ and $(R)$-CPP $(5 \mu \mathrm{M})$ to block glutamatergic synaptic currents, and the $\mathrm{GABA}_{\mathrm{A}}$ receptor antagonist bicuculline (which was present in all other types of experiments) was omitted. The chloride reversal potential in our internal solution is close to $0 \mathrm{mV}$, and the cells were held at $-60 \mathrm{mV}$; IPSCs are therefore detected as inward currents. Application of muscarine increased the sIPSC frequency in CA3 pyramidal cells (Fig. $\left.5 B_{1}\right)$ from $0.3 \pm 0.2 \mathrm{~Hz}(N=$ $5)$ in control to $2.0 \pm 0.4 \mathrm{~Hz}(N=5)$ (Fig. $\left.5 B_{2}\right)$.

To investigate whether this increase in inhibitory activity had an influence on excitatory transmission, we recorded NMDARmediated EPSCs onto CA3 pyramidal cells, but we initially did not include a $\mathrm{GABA}_{\mathrm{B}}$ antagonist in our external solution. The connection of the MF bundle to the dentate gyrus was severed in those experiments. Muscarine $(10 \mu \mathrm{M})$ decreased both $\mathrm{A} / \mathrm{C}$ and MF EPSC amplitudes (Fig. $5 C_{1}$ ) for these conditions. However, the $\mathrm{MF}$ but not the $\mathrm{A} / \mathrm{C}$ fiber depression was reversible after application of the $\mathrm{GABA}_{\mathrm{B}}$ receptor antagonist CGP 55845A (1 $\mu \mathrm{M})$ or SCH50911 $(20 \mu \mathrm{M})$. In control conditions MF synaptic release was on average reduced to $72 \%$ of control $( \pm 7 \% ; N=4)$ by muscarine. Application of the $\mathrm{GABA}_{\mathrm{B}}$ antagonist prevented this reduction $(100 \pm 8 \% ; N=10)$ (Fig. $\left.5 C_{2}\right)$. These results indicate that muscarine can indirectly inhibit MF synapses by activating inhibitory cells that release GABA and activate presynaptic $\mathrm{GABA}_{\mathrm{B}}$ receptors.

The properties of MF synapses make them potentially sensitive to another type of indirect modulation. The MF system is well known to exhibit prominent frequency facilitation even for frequencies as low as $0.1 \mathrm{~Hz}$ (Regehr et al., 1994; Salin et al., 1996). If muscarine alters the spontaneous activity of granule cells, synaptic strength would be indirectly affected. We performed a series of experiments to test this possibility. We found that muscarine increased the action potential frequency of granule cells (Misgeld et al., 1989) (Fig. 6 $A_{1}$ ). The rate of spiking was highly variable. The average action potential frequency increased from $0.05 \pm 0.05 \mathrm{~Hz}(N=5)$ in control conditions to $1.6 \pm 0.4 \mathrm{~Hz}$ $(N=5)$ (Fig. $6 A_{2}$ ). We have therefore compared the effect of muscarine $(10 \mu \mathrm{M})$ application on MF synaptic transmission in intact slices with preparations in which the cell bodies of the granule cells were separated from the MF bundle. $\mathrm{GABA}_{\mathrm{B}}$ receptors were blocked during these experiments. As shown in a representative case, muscarine increased the EPSC amplitude, and the extent of inhibition by L-CCG-I established that this was an MF input (Fig. 6 $B_{1}$ ). Muscarine increased the MF EPSC amplitude to $149 \pm 11 \%(N=4)$ of control in intact slices but had no effect on MF synaptic transmission (99 $\pm 7 \% ; N=10$ ) (Fig. $6 B_{2}$ ) when the connection to the granule cell bodies was severed. Thus, muscarine can indirectly modulate MF synapses by increas- 


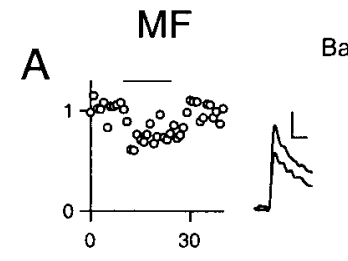

Baclofen

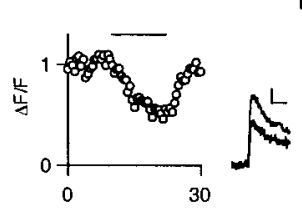

L-CCG-I
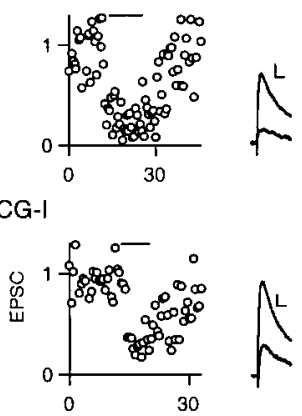

Muscarine
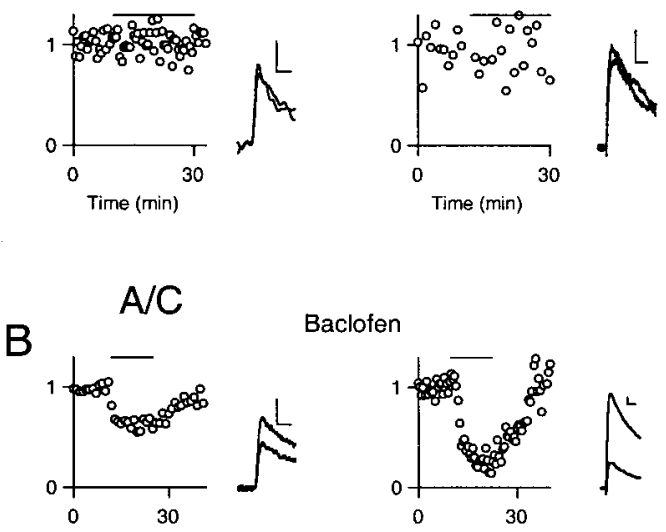

Baclofen

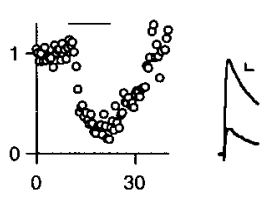

L-CCG-I
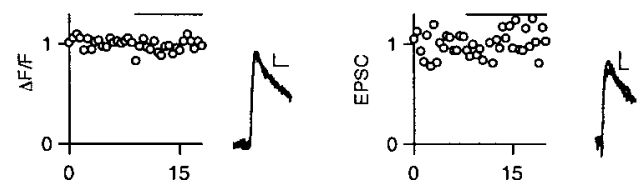

Muscarine
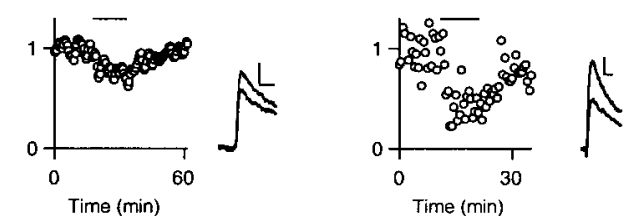

$\mathrm{C}_{1}$

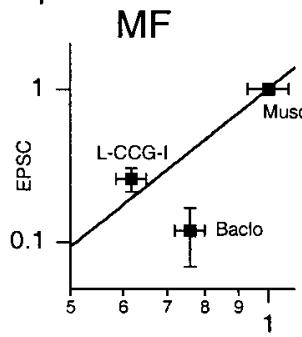

Peak $\Delta F / F$

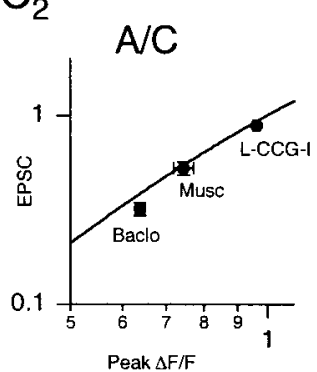

Figure 4. The effect of presynaptic modulators on presynaptic calcium influx and synaptic strengths. Traces were normalized to control. Drug applications are indicated by horizontal lines. $A, B$, Response of peak magnesium green $\Delta F / F$ (left) and NMDAR-mediated EPSC amplitude (right) to baclofen, L-CCG-I, and muscarine in the MF system $(A)$ and in the A/C system $(B)$. Insets, Averages of $10-20 \Delta \mathrm{F} / \mathrm{F}$ transients (left) and NMDAR-mediated EPSCs (right) before and during (smallest trace) drug application. Calibration: vertical, $0.2 \% \Delta F / F(A), 20 \mathrm{pA}(B)$; horizontal, 10 msec $(A), 20 \mathrm{msec}(B) . C$, Log plots of the EPSC amplitudes versus peak $\Delta F / F$ changes for the indicated experimental conditions for $\mathrm{MF}\left(C_{1}\right)$ and $\mathrm{A} / \mathrm{C}\left(C_{2}\right)$ responses. The solid lines in $C$ are the fits described in Figure 3. Means are of 4-10 experiments for each manipulation. Baclo, Baclofen; Musc, muscarine.
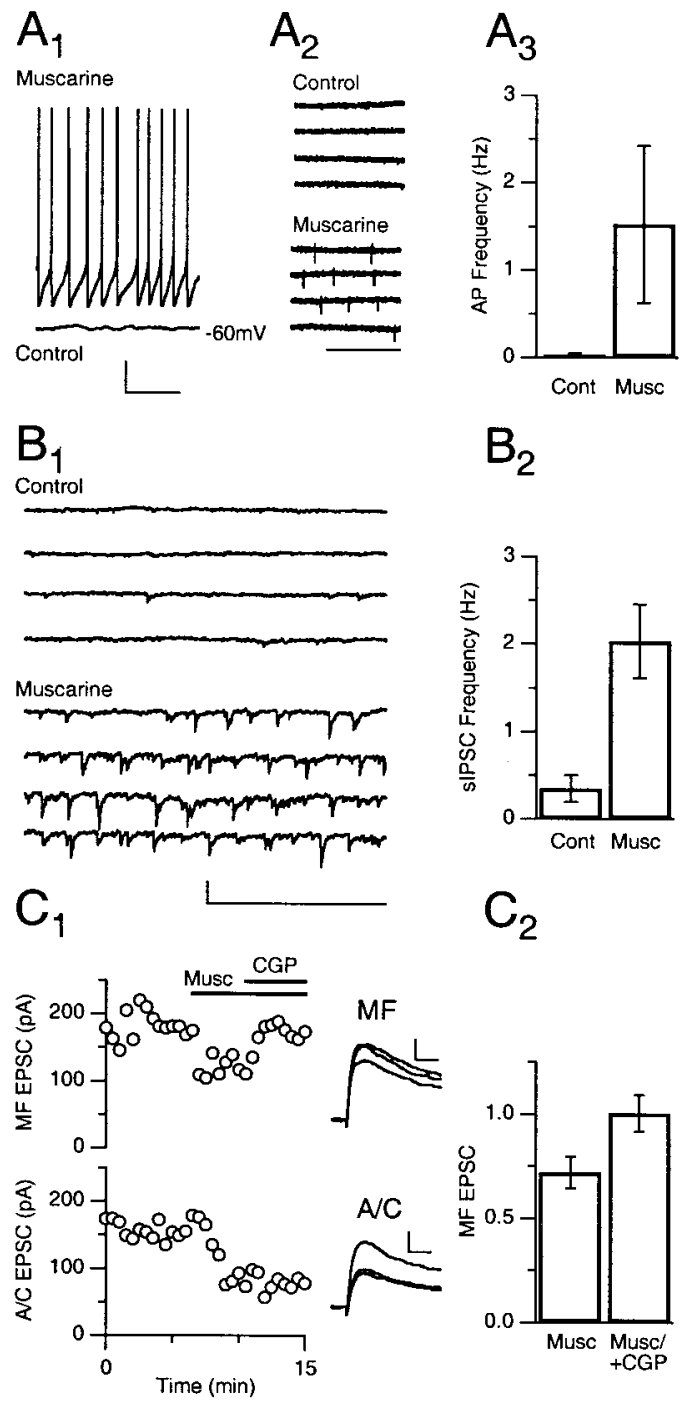

Figure 5. Muscarine depolarizes CA3 interneurons and causes heterosynaptic depression of MF release. $A_{1}$, Current-clamp whole-cell recording of a CA3 interneuron before and after the application of muscarine. Calibration: vertical, $10 \mathrm{mV}$; horizontal, 1 sec. $A_{2}$, Example of a cell-attached recording of a CA3 interneuron under control conditions and during the application of muscarine. Calibration: horizontal, $1 \mathrm{sec}$. $A_{3}$, Summary of the effect of muscarine on interneuronal firing in cellattached recordings $(N=4) . B_{1}$, Example of sIPSCs in a whole-cell recording from a $\mathrm{CA} 3$ pyramidal cell under control conditions and during the presence of muscarine. Calibration: vertical, $50 \mathrm{pA}$; horizontal, $1 \mathrm{sec}$. $B_{2}$, Average sIPSC frequency under control conditions and during the presence of muscarine $(N=4) . C_{1}$, Example of the MF (top) and A/C (bottom) NMDAR-mediated EPSC amplitude response to the application of muscarine and the subsequent addition of the $\mathrm{GABA}_{\mathrm{B}}$ antagonist CGP. Insets, Average traces for the respective conditions. Calibration: vertical, $20 \mathrm{pA}$; horizontal, $20 \mathrm{msec}$. $C_{2}$, Summary of the relative effects of muscarine alone $(N=4)$ and muscarine and CGP $(N=10)$ on MF EPSC amplitude. AP, Action potential; Cont, Control.

ing the frequency of granule cell firing, which in turn increases synaptic strength via frequency-dependent facilitation.

\section{The effect of nicotinic receptor agonists on MF calcium levels}

Another leading hypothesis for the way in which cholinergic signaling influences the CA3 region of the hippocampus is by activating presynaptic $\alpha 7$ nicotinic acetylcholine receptors (Gray et al., 1996). Activation of these calcium-permeable receptors 

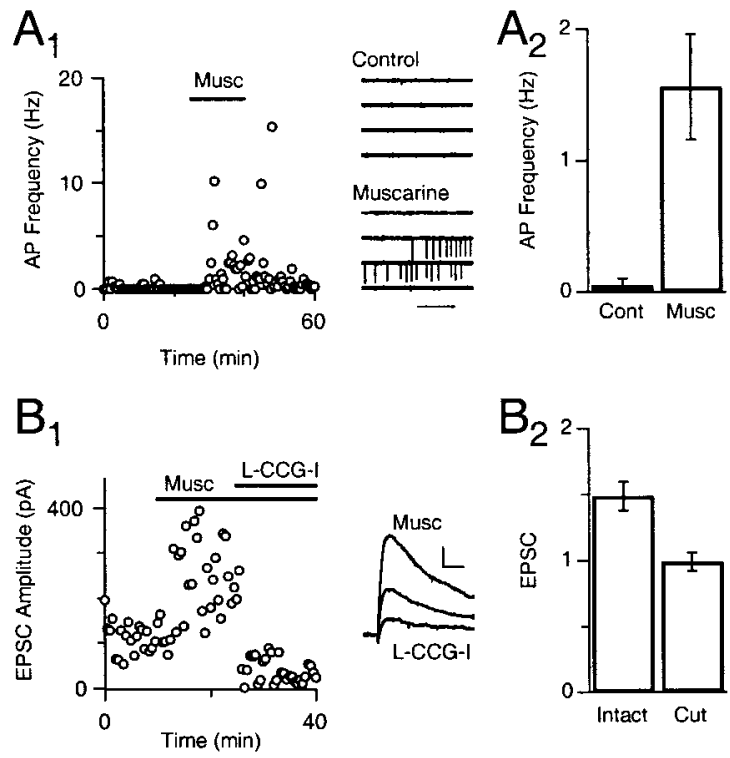

Figure 6. Muscarine elevates firing rates of granule cells and causes mossy fiber synaptic enhancement. $A_{1}$, Example of the effect of muscarine on the firing rate of a granule cell. Inset, Representative traces in control conditions and in the presence of muscarine. Calibration: horizontal, 2 sec. $A_{2}$, Summary of the effect of muscarine on granule cell-firing frequency $(N=5)$. $B_{1}$, Example of muscarine-mediated increase of NMDAR-mediated MF EPSC amplitude. Muscarine and L-CCG-I were applied as indicated (horizontal lines). Inset, Average EPSCs for the respective conditions. Calibration: vertical, $50 \mathrm{pA}$; horizontal, $20 \mathrm{msec}$. $B_{2}$, Average effect of muscarine on MF EPSC amplitude in intact slices $(N=4)$ and when the MF tract was cut $(N=6)$.

(Seguela et al., 1993) is thought to increase residual calcium levels in MF presynaptic terminals, thereby influencing the probability of release. An important piece of evidence in support of this hypothesis is that application of nicotinic receptor agonists decreases the fluorescence of MF labeled with fura-2 for $380 \mathrm{~nm}$ excitation.

We examined this effect on presynaptic calcium signaling with an approach similar to that used previously (Gray et al., 1996). As in past studies, drugs were rapidly applied with pressure to minimize the extent of desensitization, which is prominent for $\alpha 7$ nicotinic receptors. MF tracts were labeled with fura-2, which has the advantage that its high affinity makes it sensitive to even small increases in presynaptic calcium. One difference in our study was that we took advantage of the ability to use fura- 2 as a ratiometric indicator (Grynkiewicz et al., 1985) for which an increase in calcium decreases fluorescence for $380 \mathrm{~nm}$ excitation and increases fluorescence for $350 \mathrm{~nm}$ excitation. Excitation with both wavelengths is an important means of determining whether the fluorescence changes reflect alterations in calcium levels or movement. A fluorescence change arising from movement of fluorescent fibers would not show the wavelength dependence that is characteristic of a change in calcium.

The response to stimulation of the MF tract illustrates the dependence of the direction of the fluorescence signal on the excitation wavelength. Calcium transients evoked by extracellular stimulation gave rise to large decreasing fluorescence transients for $380 \mathrm{~nm}$ excitation (Fig. 7A). The smaller increasing signal observed for $350 \mathrm{~nm}$ excitation indicates that we are on the other side of the isosbestic point for excitation. Application of $\mathrm{KCl}(30$ $\mathrm{mm})$ by pressure ejection reliably evoked similar wavelength-
A

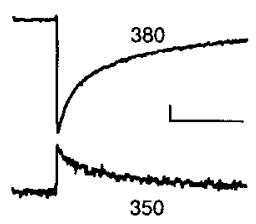

B
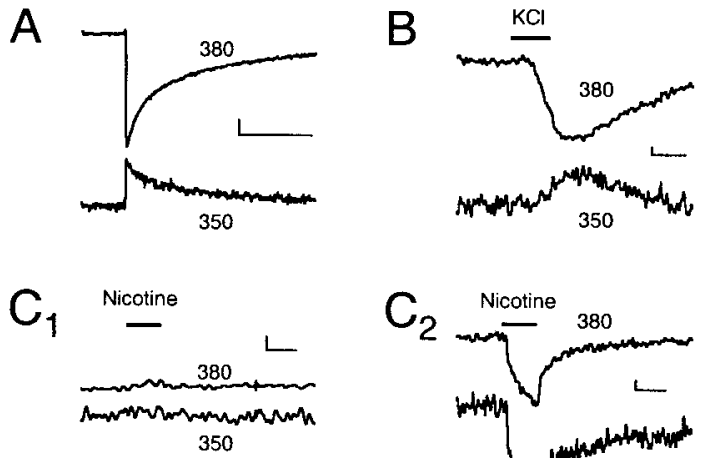

$\mathrm{C}_{2}$

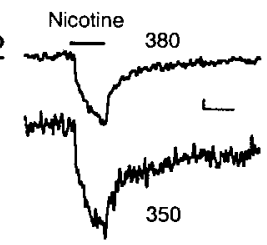

$D_{1}$

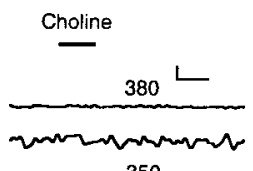

$D_{2}$

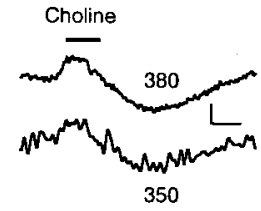

$E_{1}$
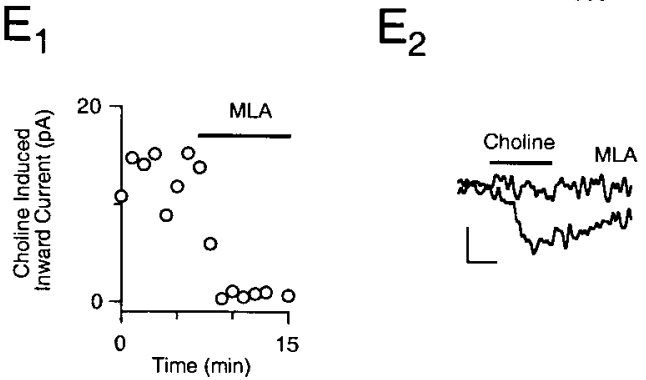

Figure 7. Mossy fiber terminals are not responsive to the nicotinic agonists nicotine and choline. $A$, Fluorescence transient from an MF tract labeled with fura-2. $\Delta F / F$ traces at 350 and $380 \mathrm{~nm}$ excitation wavelengths as a response to extracellular stimulation are shown. $B, \mathrm{MF}$ fura- $\Delta \nabla F / F$ transients at 380 and $350 \mathrm{~nm}$ as a response to focal application of $\mathrm{KCl} C$, Focal application of nicotine $(20 \mu \mathrm{M})$ and recording of $\Delta F / F$ transients at 350 and $380 \mathrm{~nm}$. $C_{1}$, Application at a distance similar to the one used in $B$. $C_{2}$, Application of nicotine at close range. $D$, Focal application of the nicotinic acetylcholine receptor agonist choline $(3 \mathrm{~mm})$ to a fura-2labeled MF tract. $D_{1}$, Placement of application pipette similar to that in B. $D_{2}$, Application pipette in close proximity to the labeled tract. Calibration $(A-D)$ : vertical, $1 \%$; horizontal, 1 sec. Traces are averages of $10-20$ trials. $E$, Whole-cell currents from an interneuron in voltage clamp as a response to focal choline application. $E_{1}$, Amplitude response under control conditions and during MLA application. $E_{2}$, Averages of five current traces under the respective conditions. Calibration: vertical, 10 $\mathrm{pA}$; horizontal, $0.5 \mathrm{sec}$.

dependent increases in fura-2 fluorescence (Fig. $7 B$ ), consistent with an increase in calcium $(N=5)$.

Application of nicotine $(20 \mu \mathrm{M})$ in the same manner did not alter fura-2 fluorescence (Fig. $7 C_{1}$ ). If the application pipette was brought close to the labeled tract (Fig. $7 C_{2}$ ), a decrease in fura-2 fluorescence at the $380 \mathrm{~nm}$ excitation wavelength could again be observed, which was accompanied by a similar decrease in fluorescence for $350 \mathrm{~nm}$ excitation. Injection of saline carrier alone had the same effect (data not shown).

We also tested the nicotinic receptor agonist choline, which has the advantage that receptor desensitization is much less pronounced compared with that with nicotine (Alkondon et al., 1997). The results were similar to those of nicotine. Choline (3 $\mathrm{mm}$ ) did not alter fura-2 florescence (Fig. $7 D_{1}$ ). Fluorescence changes were only observed if the application pipette was brought very close to the labeled tract $\left(\right.$ Fig. $\left.7 D_{2}\right)$. No changes in fura-2 
fluorescence compatible with calcium increases were produced by either nicotine $(N=5)$ or choline $(N=5)$.

As a positive control, our ability to activate nicotinic receptors with our method of agonist application was assessed. We found that with the same method of choline application, we could reliably evoke inward currents in CA3 interneurons as assessed by whole-cell voltage-clamp recordings. For all cells tested (four of four) this inward current was blocked by the specific $\alpha 7$ nicotinic receptor antagonist methyllycaconitine (MLA) (10 nM) (Fig. $\left.7 E_{1}, E_{2}\right)$. These results demonstrate that our method of agonist application can reliably activate $\alpha 7$ nicotinic receptors.

\section{DISCUSSION}

\section{Comparison of MF and A/C synapses}

Our findings extend the differences in the modulatory profile of $\mathrm{MF}$ and $\mathrm{A} / \mathrm{C}$ synapses. It has long been known that mGluRII activation inhibits MF synapses without affecting A/C synapses (Manzoni et al., 1995; Kamiya et al., 1996), and this has been used to distinguish between these two inputs. We found muscarine to have complimentary actions in that it directly inhibits the $\mathrm{A} / \mathrm{C}$ synapse without directly affecting the MF synapse. Thus, muscarine could be used to depress $\mathrm{A} / \mathrm{C}$ fiber signaling selectively during MF investigation.

Direct effects on synaptic strength mediated by $\mathrm{GABA}_{\mathrm{B}}$ receptors, muscarine receptors, and mGluRII receptors were primarily a consequence of inhibition of presynaptic calcium entry. We found that mGluRII-mediated inhibition of the MF synapse could be explained entirely by inhibition of presynaptic calcium entry [but see Kamiya and Ozawa (1999)]. Presynaptic calcium influx was reduced in both synapses by $\mathrm{GABA}_{\mathrm{B}}$ receptor activation. In $\mathrm{A} / \mathrm{C}$ synapses this inhibition of calcium influx was sufficient to account for all of the presynaptic inhibition, whereas at MF synapses additional mechanisms downstream of calcium influx may also be involved (Dittman and Regehr, 1996).

\section{Muscarinic effects}

Activation of muscarinic acetylcholine receptors affects $\mathrm{A} / \mathrm{C}$ and MF synapses via multiple mechanisms. Direct presynaptic inhibition is only present at $\mathrm{A} / \mathrm{C}$ terminals, whereas MF transmission was affected by two indirect mechanisms. Taken together these results establish that the actions of $\mathrm{ACh}$ on excitatory transmission in the CA3 region are complex, and they cannot be understood simply by considering direct effects on excitatory presynaptic terminals.

The depression of release from A/C synapses by muscarine can be fully explained by a reduction of presynaptic calcium entry. Muscarine reduces presynaptic calcium entry but does not alter the presynaptic action potential waveform (Hasselmo and Schnell, 1994). This suggests that muscarine inhibits A/C synapses by G-protein-mediated calcium channel inhibition, similar to the mechanism of inhibition by muscarine of the Schaffer collateral synapse in the CA1 region (Hasselmo and Schnell, 1994; Qian and Saggau, 1997).

One way that muscarine affects MF transmission is to excite inhibitory neurons, leading to the release of GABA, which in turn activates $\mathrm{GABA}_{\mathrm{B}}$ receptors on $\mathrm{MF}$ boutons and thereby indirectly inhibits synaptic transmission (Fig. 5). Several factors make the MF synapse particularly sensitive to this type of synaptic modulation. Muscarine induces massive increases both in the firing rate of interneurons in the hippocampus and in the release of GABA. There is even a type of inhibitory neuron with a morphology suited to elevating GABA levels near MFs (Vida and
Frotscher, 2000). Moreover, MF synapses are extremely sensitive to $\mathrm{GABA}_{\mathrm{B}}$ receptor activation, and $\mathrm{MF}$ terminals are likely under a continuous dynamic GABAergic inhibition (Vogt and Nicoll, 1999).

Another way by which muscarine indirectly modulates MF synapses is to elevate the firing rate of DG cells, which in turn facilitates MF synapses. Again the MF synapse may be particularly sensitive to such modulation. The basal firing rate of DG cells is low in the slice as it is in vivo (Jung and McNaughton, 1993), and the increases in firing rate induced by muscarine are substantial. But it is the low threshold for frequency facilitation in the MF synapse that makes it particularly sensitive to changes in firing rates over the range produced by muscarine (Regehr et al., 1994; Salin et al., 1996).

Both of these indirect mechanisms of synaptic modulation are likely to be quite widespread (Frerking et al., 1999), although their contributions are certainly very synapse dependent. In the case of indirect GABAergic modulation, the lack of an indirect inhibition of the $\mathrm{A} / \mathrm{C}$ synapse in our experimental conditions suggests that it is less susceptible to such modulation, despite the presence of $\mathrm{GABA}_{\mathrm{B}}$ receptors on $\mathrm{A} / \mathrm{C}$ fibers (Fig. 4). Moreover, the manner in which alterations in the firing pattern of a presynaptic cell affect transmission depends on the use-dependent plasticity of the synapse. At facilitating synapses, such as the MF synapse, an elevation in firing enhances transmission. In contrast, for depressing synapses, increases in presynaptic firing rates depress synaptic transmission (Frerking et al., 1998).

The indirect effects of muscarine have important implications for the study of synapses in preparations with intact circuitry. Not surprisingly, because of indirect modulation, when DG connections are preserved and $\mathrm{GABA}_{\mathrm{B}}$ receptor antagonists are absent, the effects of muscarine on MF transmission are variable and difficult to interpret (data not shown). Enhancement by an indirect mechanism that requires intact connections between granule cell bodies and MF boutons is opposed by a depression that needs healthy inhibitory transmission. The extent to which either the DG connection or inhibitory neurons are preserved within a slice can be highly variable. Such complications are certainly not limited to the actions of muscarine at the MF synapse. More fundamentally, we see that to understand the effects of $\mathrm{ACh}$ on the $\mathrm{CA} 3$ region it is also necessary to consider how ACh changes the activity of cells capable of releasing modulatory chemical messengers and how ACh alters the activity in the presynaptic cell of interest.

\section{Nicotinic effects}

The possible presence of calcium-permeable nicotinic receptors on MF boutons is intriguing because elevations of presynaptic calcium greatly enhance MF synapses (Regehr et al., 1994). We were unable to detect such an increase in presynaptic calcium levels by locally applying nicotinic receptor agonists to MFs. By using two wavelengths to excite fura-2, we could distinguish between fluorescence changes caused by movement and those produced by elevations in presynaptic calcium. We found that the fluorescence changes produced by nicotine or choline reflected movement because of pressure ejection. Additional experiments suggested that our measurement approach is sufficiently sensitive to detect changes in presynaptic calcium levels that would be needed to affect neurotransmitter release. Finally, our method of agonist application could reliably evoke postsynaptic responses mediated by $\alpha 7$ nicotinic receptors in the slice. Thus, our findings do not support a prominent contribution of a mechanism of 
synaptic modulation in which activation of presynaptic nicotinic receptors enhances $\mathrm{MF}$ transmission by elevating presynaptic calcium levels.

\section{REFERENCES}

Albuquerque EX, Pereira EF, Castro NG, Alkondon M, Reinhardt S, Schroder H, Maelicke A (1995) Nicotinic receptor function in the mammalian central nervous system. Ann N Y Acad Sci 757:48-72.

Albuquerque EX, Pereira EF, Alkondon M, Schrattenholz A, Maelicke A (1997) Nicotinic acetylcholine receptors on hippocampal neurons: distribution on the neuronal surface and modulation of receptor activity. J Recept Signal Transduct Res 17:243-266.

Alkondon M, Pereira EF, Cortes WS, Maelicke A, Albuquerque EX (1997) Choline is a selective agonist of alpha7 nicotinic acetylcholine receptors in the rat brain neurons. Eur J Neurosci 9:2734-2742.

Alkondon M, Braga MF, Pereira EF, Maelicke A, Albuquerque EX (2000) Alpha7 nicotinic acetylcholine receptors and modulation of gabaergic synaptic transmission in the hippocampus. Eur J Pharmacol 393:59-67.

Amaral DG, Dent JA (1981) Development of the mossy fibers of the dentate gyrus. I. A light and electron microscopic study of the mossy fibers and their expansions. J Comp Neurol 195:51-86.

Amaral DG, Witter MP (1989) The three-dimensional organization of the hippocampal formation: a review of anatomical data. Neuroscience 31:571-591.

Bartus RT, Dean RLD, Beer B, Lippa AS (1982) The cholinergic hypothesis of geriatric memory dysfunction. Science 217:408-414.

Boyd RT (1997) The molecular biology of neuronal nicotinic acetylcholine receptors. Crit Rev Toxicol 27:299-318.

Christian EP, Dudek FE (1988) Characteristics of local excitatory circuits studied with glutamate microapplication in the CA3 area of rat hippocampal slices. J Neurophysiol 59:90-109.

Coyle JT, Price DL, DeLong MR (1983) Alzheimer's disease: a disorder of cortical cholinergic innervation. Science 219:1184-1190.

Dani JA, Mayer ML (1995) Structure and function of glutamate and nicotinic acetylcholine receptors. Curr Opin Neurobiol 5:310-317.

Deutsch JA, Rocklin KW (1967) Amnesia induced by scopolamine and its temporal variations. Nature 216:89-90.

Dittman JS, Regehr WG (1996) Contributions of calcium-dependent and calcium-independent mechanisms to presynaptic inhibition at a cerebellar synapse. J Neurosci 16:1623-1633.

Feller MB, Delaney KR, Tank DW (1996) Presynaptic calcium dynamics at the frog retinotectal synapse. J Neurophysiol 76:381-400.

Frerking M, Malenka RC, Nicoll RA (1998) Synaptic activation of kainate receptors on hippocampal interneurons [see comments]. Nat Neurosci 1:479-486.

Frerking M, Petersen CC, Nicoll RA (1999) Mechanisms underlying kainate receptor-mediated disinhibition in the hippocampus. Proc Natl Acad Sci USA 96:12917-12922.

Gray JA, McNaughton N (1983) Comparison between the behavioural effects of septal and hippocampal lesions: a review. Neurosci Biobehav Rev 7:119-188.

Gray R, Rajan AS, Radcliffe KA, Yakehiro M, Dani JA (1996) Hippocampal synaptic transmission enhanced by low concentrations of nicotine [see comments]. Nature 383:713-716.

Grynkiewicz G, Poenie M, Tsien RY (1985) A new generation of $\mathrm{Ca}^{2+}$ indicators with greatly improved fluorescence properties. J Biol Chem 260:3440-3450.

Hasselmo ME, Schnell E (1994) Laminar selectivity of the cholinergic suppression of synaptic transmission in rat hippocampal region CA1: computational modeling and brain slice physiology. J Neurosci 14:3898-3914.

Hasselmo ME, Schnell E, Barkai E (1995) Dynamics of learning and recall at excitatory recurrent synapses and cholinergic modulation in rat hippocampal region CA3. J Neurosci 15:5249-5262.

Herrington J, Bookman RJ (1995) Pulse control V4.5: IGOR XOPs for patch clamp data acquisition. Miami: University of Miami.

Huerta PT, Lisman JE (1993) Heightened synaptic plasticity of hippocampal CA1 neurons during a cholinergically induced rhythmic state. Nature 364:723-725.

Hulme EC, Birdsall NJ, Buckley NJ (1990) Muscarinic receptor subtypes. Annu Rev Pharmacol Toxicol 30:633-673.
Jung MW, McNaughton BL (1993) Spatial selectivity of unit activity in the hippocampal granular layer. Hippocampus 3:165-182.

Kamiya H, Ozawa S (1999) Dual mechanism for presynaptic modulation by axonal metabotropic glutamate receptor at the mouse mossy fibre-CA3 synapse. J Physiol (Lond) 518:497-506.

Kamiya H, Shinozaki H, Yamamoto C (1996) Activation of metabotropic glutamate receptor type $2 / 3$ suppresses transmission at rat hippocampal mossy fibre synapses. J Physiol (Lond) 493:447-455.

Levey AI, Edmunds SM, Koliatsos V, Wiley RG, Heilman CJ (1995) Expression of $\mathrm{m} 1-\mathrm{m} 4$ muscarinic acetylcholine receptor proteins in rat hippocampus and regulation by cholinergic innervation. J Neurosci 15:4077-4092.

Manzoni OJ, Castillo PE, Nicoll RA (1995) Pharmacology of metabotropic glutamate receptors at the mossy fiber synapses of the guinea pig hippocampus. Neuropharmacology 34:965-971.

McGehee DS, Heath MJ, Gelber S, Devay P, Role LW (1995) Nicotine enhancement of fast excitatory synaptic transmission in CNS by presynaptic receptors [see comments]. Science 269:1692-1696.

McQuiston AR, Madison DV (1999a) Nicotinic receptor activation excites distinct subtypes of interneurons in the rat hippocampus. J Neurosci 19:2887-2896.

McQuiston AR, Madison DV (1999b) Muscarinic receptor activity induces an afterdepolarization in a subpopulation of hippocampal CA1 interneurons. J Neurosci 19:5703-5710.

Miles R, Wong RK (1987) Inhibitory control of local excitatory circuits in the guinea-pig hippocampus. J Physiol (Lond) 388:611-629.

Mintz IM, Sabatini BL, Regehr WG (1995) Calcium control of transmitter release at a cerebellar synapse. Neuron 15:675-688.

Misgeld U, Muller W, Polder HR (1989) Potentiation and suppression by eserine of muscarinic synaptic transmission in the guinea-pig hippocampal slice. J Physiol (Lond) 409:191-206.

Qian J, Saggau P (1997) Presynaptic inhibition of synaptic transmission in the rat hippocampus by activation of muscarinic receptors: involvement of presynaptic calcium influx. Br J Pharmacol 122:511-519.

Regehr WG (1999) Monitoring presynaptic calcium dynamics with membrane-permeant indicators. In: Imaging neurons (Yuste R, Lanni F, Konnerth A, eds), pp 37.1-37.11. Cold Spring Harbor, NY: Cold Spring Harbor Laboratory.

Regehr WG, Atluri PP (1995) Calcium transients in cerebellar granule cell presynaptic terminals. Biophys J [Erratum (1995) 69:729] 68:2156-2170.

Regehr WG, Tank DW (1991) Selective fura-2 loading of presynaptic terminals and nerve cell processes by local perfusion in mammalian brain slice. J Neurosci Methods 37:111-119.

Regehr WG, Delaney KR, Tank DW (1994) The role of presynaptic calcium in short-term enhancement at the hippocampal mossy fiber synapse. J Neurosci 14:523-537.

Rouse ST, Marino MJ, Potter LT, Conn PJ, Levey AI (1999) Muscarinic receptor subtypes involved in hippocampal circuits. Life Sci 64:501-509.

Safer DJ, Allen RP (1971) The central effects of scopolamine in man. Biol Psychiatry 3:347-355.

Salin PA, Scanziani M, Malenka RC, Nicoll RA (1996) Distinct shortterm plasticity at two excitatory synapses in the hippocampus. Proc Natl Acad Sci USA 93:13304-13309.

Seguela P, Wadiche J, Dineley-Miller K, Dani JA, Patrick JW (1993) Molecular cloning, functional properties, and distribution of rat brain alpha 7: a nicotinic cation channel highly permeable to calcium. J Neurosci 13:596-604.

Squire LR (1998) Memory systems. C R Acad Sci III 321:153-156.

Vida I, Frotscher M (2000) A hippocampal interneuron associated with the mossy fiber system. Proc Natl Acad Sci USA 97:1275-1280.

Vogt KE, Nicoll RA (1999) Glutamate and gamma-aminobutyric acid mediate a heterosynaptic depression at mossy fiber synapses in the hippocampus. Proc Natl Acad Sci USA 96:1118-1122.

Williams S, Johnston D (1990) Muscarinic depression of synaptic transmission at the hippocampal mossy fiber synapse. J Neurophysiol 64:1089-1097.

Wu LG, Saggau P (1997) Presynaptic inhibition of elicited neurotransmitter release. Trends Neurosci 20:204-212.

Zhao M, Hollingworth S, Baylor SM (1996) Properties of tri- and tetracarboxylate $\mathrm{Ca}^{2+}$ indicators in frog skeletal muscle fibers. Biophys $\mathbf{J}$ 70:896-916. 